\title{
Reproductive factors and lung cancer risk: a comprehensive systematic review and meta-analysis
}

\author{
Xin Yin ${ }^{1 \dagger}$, Zhiying Zhu ${ }^{2,3+}$, H. Dean Hosgood ${ }^{4}$, Qing Lan $^{2+}$ and Wei Jie Seow ${ }^{1,2,5^{*+}}$ (B)
}

\begin{abstract}
Background: A number of studies have investigated the association between reproductive factors and lung cancer risk, however findings are inconsistent. This meta-analysis aimed to evaluate the association between female reproductive factors and lung cancer risk.

Methods: We conducted a comprehensive systematic search to identify relevant and eligible studies published before 18th December 2019. Inter-study heterogeneity was assessed using the $Q$ test and $P^{2}$ statistic. Based on the heterogeneity of each reproductive factor, fixed or random effects models were used to calculate the summary odds ratios (ORs) and 95\% confidence intervals (Cls). Subgroup analyses by study design, lung cancer subtypes, smoking status, and ethnicity were also performed.

Results: A total of 66 studies with 20 distinct reproductive factors were included in this meta-analysis. Comparing the highest and lowest categories (reference) of each reproductive factor, parity $(\mathrm{OR}=0.83,95 \% \mathrm{Cl}=0.72-0.96)$, menstrual cycle length $(\mathrm{OR}=0.79,95 \% \mathrm{Cl}=0.65-0.96)$, and age at first birth $(\mathrm{OR}=0.85,95 \% \mathrm{Cl}=0.74-0.98)$, were significantly associated with a lower risk of overall lung cancer. On the contrary, non-natural menopause was significantly associated with higher lung cancer risk $(\mathrm{OR}=1.52,95 \% \mathrm{Cl}=1.25-1.86)$. Among never-smokers, a significant negative association was found between parity and lung cancer risk. Both parity and non-natural menopause were statistically significant in case-control studies.
\end{abstract}

Conclusion: These results suggest that certain reproductive factors may be associated with lung cancer risk. Future studies should further validate the associations, and investigate the underlying mechanisms.

Keywords: Lung cancer, Meta-analysis, Reproductive factors, Never-smokers, Parity

\footnotetext{
* Correspondence: ephswj@nus.edu.sg

Qing Lan and Wei Jie Seow these authors co-supervised the work.

${ }^{1}$ Saw Swee Hock School of Public Health, National University of Singapore

and National University Health System, Singapore 117549, Singapore

${ }^{2}$ Division of Cancer Epidemiology and Genetics, National Cancer Institute,

National Institutes of Health, Rockville, MD 20850, USA

Full list of author information is available at the end of the article
}

(C) The Author(s). 2020 Open Access This article is licensed under a Creative Commons Attribution 4.0 International License, which permits use, sharing, adaptation, distribution and reproduction in any medium or format, as long as you give appropriate credit to the original author(s) and the source, provide a link to the Creative Commons licence, and indicate if changes were made. The images or other third party material in this article are included in the article's Creative Commons licence, unless indicated otherwise in a credit line to the material. If material is not included in the article's Creative Commons licence and your intended use is not permitted by statutory regulation or exceeds the permitted use, you will need to obtain permission directly from the copyright holder. To view a copy of this licence, visit http://creativecommons.org/licenses/by/4.0/. The Creative Commons Public Domain Dedication waiver (http://creativecommons.org/publicdomain/zero/1.0/) applies to the data made available in this article, unless otherwise stated in a credit line to the data. 


\section{Background}

Lung cancer is the leading cause of cancer death worldwide among both men and women [1]. Despite cigarette smoking being the predominant carcinogen for lung cancer risk, it only contributes to approximately half of the lung cancer cases among women, since most women are never-smokers [2]. Among never smokers, the rate of lung cancer incidence was reported to be higher in women than in men [3], and a reduction in smoking prevalence decreased lung cancer mortality rate in men, but not in women [4]. Studies have suggested that women, by being more susceptible to carcinogens in tobacco smoke [5, 6], may have a higher chance of developing lung cancer at a younger age and with less smoking intensity than men [7-9].

Reproductive and hormonal factors have been hypothesized to be influential stimuli to lung cancer carcinogenesis. Previous studies have detected estrogen receptors in both normal and cancerous lung tissues [10, 11], higher rates of epidermal growth factor receptor (EGFR) mutation-positive lung cancer in never-smoking women [12], familial aggregation of reproductive cancers among female lung cancer patients [13, 14], and increased lung cancer risk in female cancer survivors with a history of reproductive-related primary tumors [15-21]. However, results from epidemiological studies investigating the relationship between hormonal and reproductive factors with lung cancer risk are conflicting. For example, some studies suggested a significant decrease of female lung cancer risk with increased parity [22-24] or hormone use [25-27], whereas other studies reported the opposite, a positive association between increased parity $[28,29]$ or hormone use $[30,31]$ and lung cancer risk.

To evaluate the association between female reproductive factors and lung cancer risk, we conducted a comprehensive systematic review and meta-analysis and stratified by ethnicity, smoking status, study design, and histology.

\section{Methods}

\section{Literature search and identification of eligible studies}

A systematic literature search was performed by two independent reviewers using the following search terms: reproductive, estrogen, hormone, birth, menopause, menarche, oral contraceptive, parity, pregnancy AND women AND lung cancer, using PubMed, Chinese National Knowledge Infrastructure (CNKI), National University of Singapore Library, and Google Scholar databases before December 2019, restricted to English and Chinese language papers. The detailed search strategy was developed for PubMed and adapted for other databases (Supplementary Table S1). Relevant publications from the reference lists of identified papers were also extensively reviewed to include additional studies in order to avoid missing any potential publications during the database search. Studies were scrutinized for their eligibility to be included in our analysis using the following inclusion criteria: 1) the study design was either case-control, cohort, or randomized controlled trial; 2) the outcome of interest was either overall lung cancer or lung cancer subtypes (adenocarcinoma (AC), squamous cell carcinoma (SCC), small cell lung cancer (SCLC) and non-small-cell lung cancer (NSCLC)); 3) the exposure variables were related to reproductive, menstrual, or hormonal factors; 4) if there were repeated studies published by the same group of authors, only the most recently updated publication was included, unless different study designs were used. Studies were excluded if they did not specify the reference group used, reference group overlapped, or if they did not include a measure of association.

\section{Data extraction}

Information was extracted from each of the selected studies and recorded as the following variables: last name and initial of first name of the first author, publication year, journal name, reproductive factors, nonreference (the highest or the lowest) and reference group, study population (e.g., Asian, Caucasian, or Mixed), lung cancer subtype (AC, SCC, NSCLC or SCLC), study design (case-control, cohort, randomized clinical trial), number of cases and controls, smoking status (if applicable, never smokers, past smokers, current smokers), presence of EGFR mutation (if applicable), association estimates (odds ratios (ORs) or risk ratios (RRs) for case-control studies, risk ratios (RRs), standardized incidence ratios (SIRs) or hazard ratios (HRs) for cohort studies), 95\% confidence intervals (CIs) and $P$-values for the non-reference group (for categorical variables) or for the continuous interval (for continuous variables), or P-trend with the corresponding statistical adjustments. As hormone replacement therapy type medications were reported in many different ways, including estrogen plus progestin (EPT), estrogen alone (E), hormone replacement therapy (HRT), hormone use, and postmenopausal hormone therapy, we combined them into an ever/never use of hormones variable; women with current and former smoking status were combined as "ever smokers" category. We recalculated the overall total effect using meta-analyses if the original paper only provided the separate effect for these single categories.

\section{Statistical analysis}

Pooled estimates were calculated as the inverse varianceweighted mean of the logarithm of OR with $95 \%$ confidence interval $(\mathrm{CI})$ to assess the association between 
reproductive factors and lung cancer risk. Heterogeneity among the included studies was evaluated using the $Q$ test, and $I^{2}$ statistic that represents the proportion of total variation attributable to inter-study heterogeneity. In the presence of substantial heterogeneity $\left(I^{2}>50 \%\right)$ [32], the random effects model was used as the pooling method; otherwise, the fixed effects model was applied. We also stratified the meta-analysis by study design (case-control, cohort or randomized clinical trial), lung cancer subtypes (overall lung cancer, AC or NSCLC), smoking status (never smokers or ever smokers), and ethnicity (Asian, Caucasian, or Mixed) for reproductive factors.

Assessment for potential publication bias was conducted using Egger's linear regression analysis and trimand-fill method. The 'leave one out' sensitivity analysis was carried out to assess potential heterogeneity and the robustness of the findings [33, 34].
To assess the quality of our included studies, we performed the Newcastle-Ottawa Scale (NOS) for observational studies and the Cochrane Risk of Bias Tool (CRBT) assessment for randomized controlled trials. For those studies with poor quality and high risk of bias (NOS score $\leq 5$ or CRBT score $<4$ ), we excluded them for the sensitivity analysis.

This meta-analysis followed the Preferred Reporting Items for Systematic Reviews and Meta-Analyses (PRIS MA) guidelines [35]. All statistical analysis was conducted using Stata version 15.0 (Stata Corporation, College Station, Texas, USA). All statistical tests were conducted as two-sided, and a $P$-value of $<0.05$ was considered as being statistically significant.

\section{Results}

The literature search identified 2050 publications from the databases and 3 additional studies were retrieved

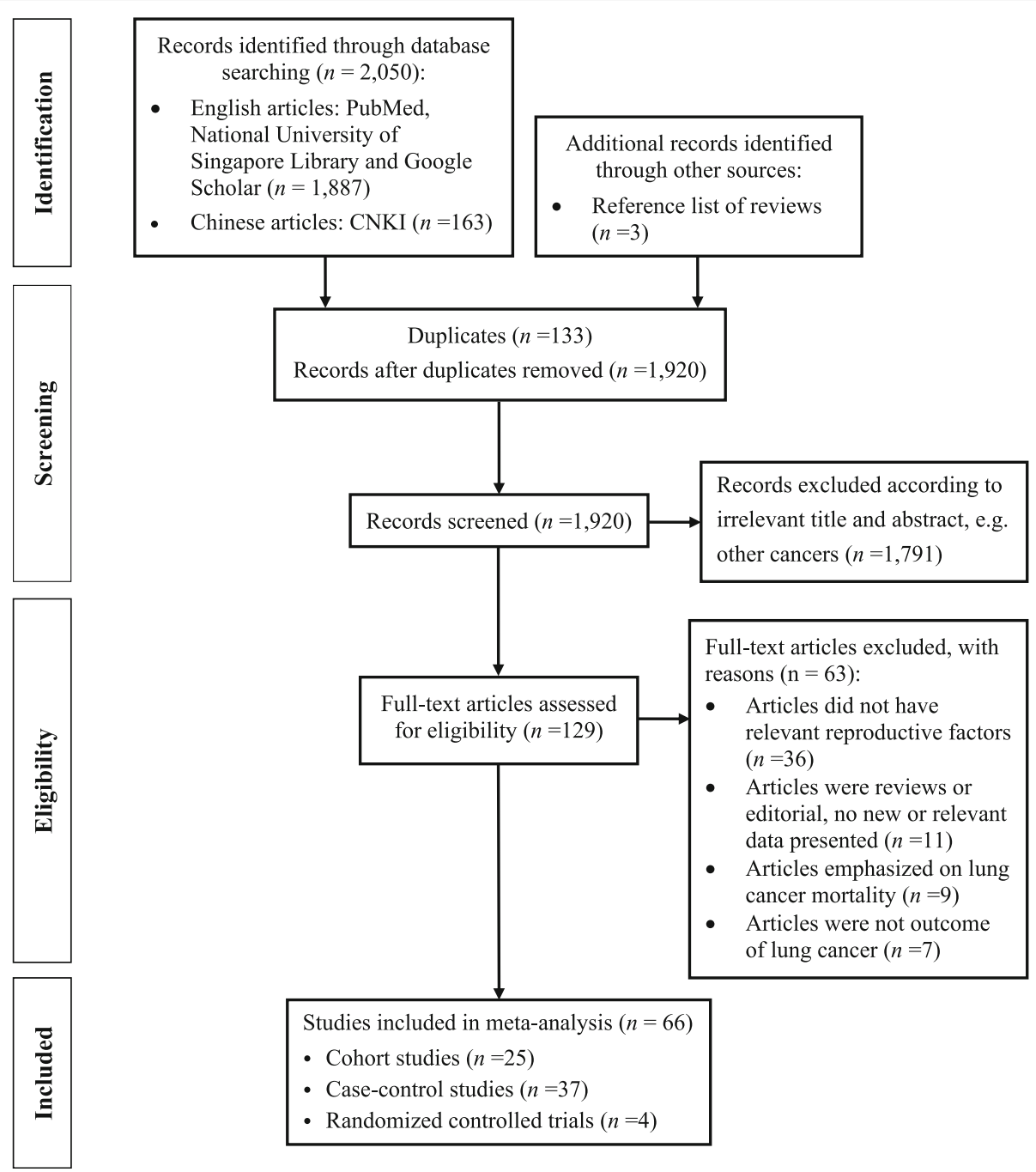

Fig. 1 Flowchart of study selection, inclusion, and analysis 
from the reference lists of previous meta-analysis studies that were identified through the search terms. A total of 133 duplicates, 1791 irrelevant publications, and 63 studies with full-text screening were excluded. Finally, 66 studies were eligible for inclusion into this meta-analysis [22-28, 31, 36-93] (Fig. 1). The characteristics of the 66 selected studies are shown in Supplementary Table S2, Additional file 1 . In total, there were 25 cohort studies, 37 case-control studies, and four randomized controlled trials. The publication years of these studies ranged from 1987 to 2019. Collectively, 26 studies were conducted among Asian females, 25 studies among Caucasian females, and 15 studies among mixed ethnicities. Of the 66 selected studies, 20 studies further stratified by smoking status, and 23 studies stratified by lung cancer subtypes (AC, SCC, NSCLC or SCLC). A total of 31 reproductive factors were extracted from the selected studies, with 20 reproductive factors included in the metaanalysis after combining some of the factors due to the sparse number of eligible studies (Table 1 and Fig. 1). Among these exposures, we found statistical significance for four reproductive variables with overall lung cancer risk: parity, age at first birth, non-natural menopause, and menstrual cycle length (Fig. 2). Other forest plots are shown in Supplementary Fig. S1, Additional file 2.

\section{Parity}

Twenty-four studies reported the association between parity and overall lung cancer risk. A total of 10 studies stratified by lung cancer subtypes. The highest parity category ranged from $\geq 3$ to $\geq 7$ children, while the lowest parity category ranged from 0 to 2 children. The pooled ORs were $0.83\left(95 \% \mathrm{CI}=0.72-0.96, I^{2}=75.4 \%\right)$ for overall lung cancer, $0.84\left(95 \% \mathrm{CI}=0.63-1.11, I^{2}=75.1 \%\right)$ for NSCLC, and $0.83\left(95 \% \mathrm{CI}=0.63-1.09, I^{2}=67.0 \%\right)$ for adenocarcinoma (Tables 1 and 2). Specifically, a significant negative association of higher parity and overall lung cancer risk was found among Asians $(\mathrm{OR}=0.70$, 95\% CI $=0.58-0.86, I^{2}=59.7 \%$ ), but no association was observed among Caucasians. After further stratification by study design, and lung cancer subtype, higher parity was significantly associated with decreased risks of overall lung cancer $\left(\mathrm{OR}=0.58,95 \% \mathrm{CI}=0.44-0.75, I^{2}=\right.$ $45.3 \%)$, non-small cell lung cancer $(\mathrm{OR}=0.39,95 \% \mathrm{CI}=$

Table 1 Association of reproductive factors and overall lung cancer risk (highest vs. lowest category)

\begin{tabular}{|c|c|c|c|c|c|c|}
\hline Reproductive factors & Highest category & Lowest category (reference) & No. of studies & $P_{\text {het }}{ }^{a}$ & $I^{2}$ value $(\%)$ & OR $(95 \% \mathrm{Cl})^{\mathrm{b}}$ \\
\hline \multicolumn{7}{|l|}{ Menstrual-related factors } \\
\hline Age at menopause & $\geq 50$ to $\geq 55$ & Premenopausal or $<50$ & 22 & $<0.001$ & 64.3 & $0.99(0.88,1.12)$ \\
\hline Age at menarche & $\geq 15$ to $\geq 18$ & $<11$ to $\leq 15$ & 20 & 0.032 & 40.4 & $1.03(0.96,1.10)$ \\
\hline Non-natural menopause & Non-natural & Natural / premenopausal & 11 & 0.013 & 55.3 & $1.52(1.25,1.86)$ \\
\hline Ovariectomy & yes & no & 5 & 0.487 & 0.0 & $1.38(1.16,1.64)$ \\
\hline Hysterectomy & yes & no & 4 & 0.171 & 40.1 & $1.21(0.98,1.49)$ \\
\hline Ovariectomy and Hysterectomy & yes & no & 4 & 0.405 & 0.0 & $1.22(0.95,1.58)$ \\
\hline Menstrual cycle length & $>30$ days & $<27$ to $\leq 30$ days & 7 & 0.106 & 42.7 & $0.79(0.65,0.96)$ \\
\hline Menopausal status & Post-menopausal & Pre-menopausal & 6 & 0.057 & 53.4 & $1.26(0.92,1.73)$ \\
\hline Length of menstrual flow (days) & $\geq 5$ to $>6$ & $\leq 3$ to $<5$ & 4 & 0.712 & 0.0 & $1.01(0.84,1.23)$ \\
\hline \multicolumn{7}{|l|}{ Other factors } \\
\hline Hormone use & ever & never & 38 & $<0.001$ & 56.6 & $0.95(0.90,1.01)$ \\
\hline Oral contraceptive use & ever & never & 26 & 0.003 & 48.2 & $1.01(0.94,1.09)$ \\
\hline OC use duration (years) & $\geq 2$ to $\geq 12$ & 0 to $<2$ & 12 & 0.012 & 54.5 & $0.99(0.87,1.14)$ \\
\hline Parity & $\geq 3$ to $\geq 7$ & 0 to 2 & 24 & $<0.001$ & 75.4 & $0.83(0.72,0.96)$ \\
\hline Number of pregnancy & $\geq 4$ to $\geq 7$ & 0 to 2 & 10 & 0.002 & 66.3 & $0.91(0.73,1.15)$ \\
\hline Age at first birth & $\geq 25$ to $\geq 31$ & Nulliparous or $<25$ & 19 & $<0.001$ & 62.7 & $0.85(0.74,0.98)$ \\
\hline Reproductive period (years) & $\geq 36$ to $\geq 41$ & $\leq 30$ to $<33$ & 8 & 0.048 & 50.6 & $0.95(0.78,1.17)$ \\
\hline Breastfeeding & ever & never & 6 & 0.330 & 13.2 & $0.94(0.83,1.06)$ \\
\hline Miscarriage & ever & never & 4 & 0.063 & 58.9 & $1.20(0.93,1.56)$ \\
\hline Tubal sterilization use & ever & never & 4 & 0.019 & 69.7 & $1.05(0.84,1.33)$ \\
\hline Intrauterine device use & ever & never & 4 & 0.097 & 52.5 & $0.83(0.66,1.04)$ \\
\hline
\end{tabular}

a Heterogeneity $P$-value

${ }^{\mathrm{b}}$ Adjusted odds ratio $(\mathrm{OR})$ and $95 \%$ confidence interval $(\mathrm{Cl})$. Highest non-reference category as compared to the lowest reference group 


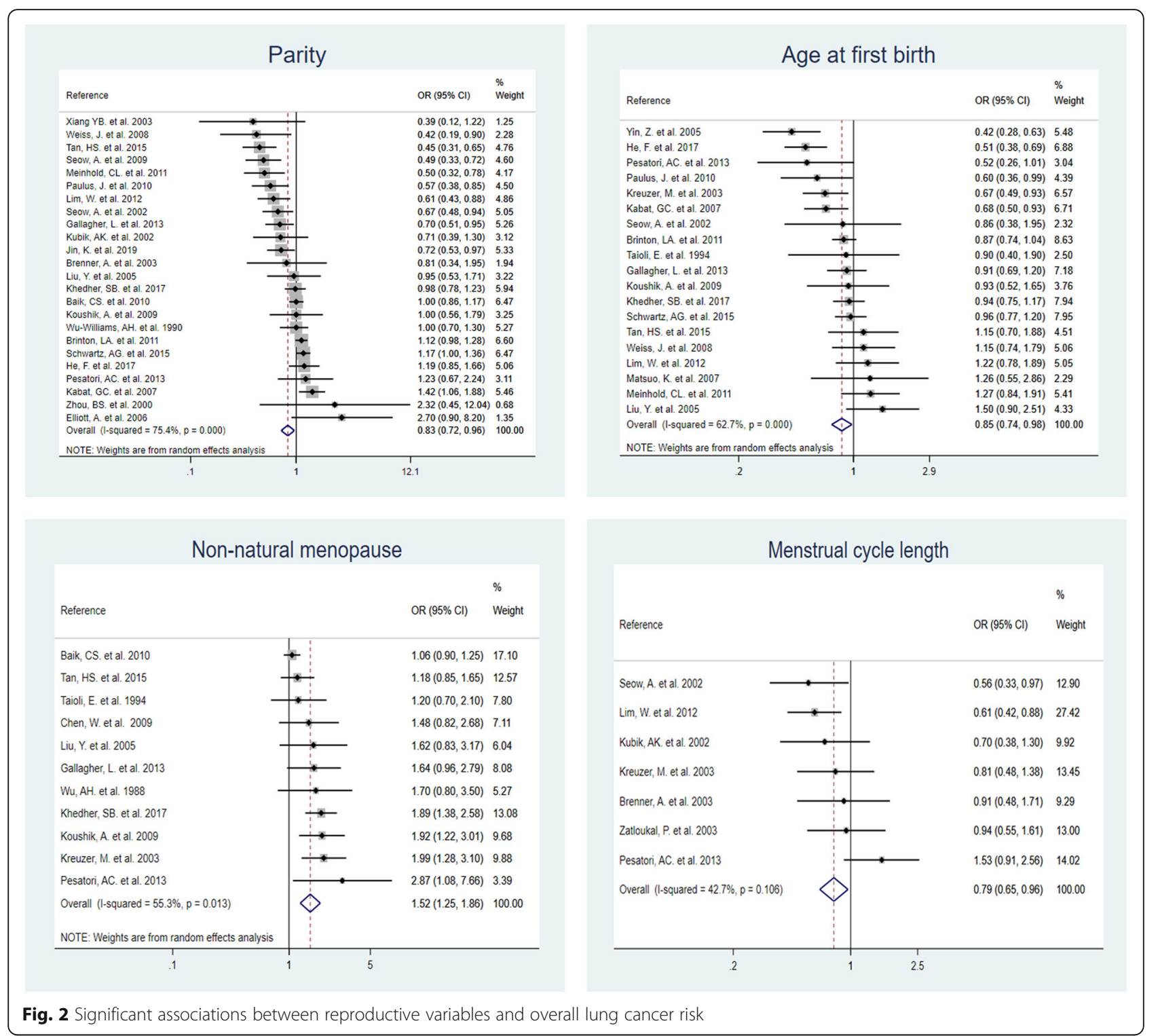

0.18-0.84, $\left.I^{2}=25.3 \%\right)$ and lung adenocarcinoma (OR = 0.45, 95\% CI $\left.=0.28-0.71, I^{2}=30.0 \%\right)$ among Asian women in cohort studies.

Eleven studies assessed parity and lung cancer risk among never-smokers while 8 studies assessed the association among ever-smokers. For overall lung cancer, the ORs for Asian women were 0.65 (95\% CI $=0.54-$ $\left.0.78, I^{2}=0.0 \%\right)$ among never-smokers and $0.54(95 \%$ $\left.\mathrm{CI}=0.40-0.75, I^{2}=0.0 \%\right)$ among ever smokers. Among case-control studies, higher parity was also significantly negatively associated with overall lung cancer risk among never smokers $(\mathrm{OR}=0.65,95 \% \mathrm{CI}=0.52-0.81$, $\left.I^{2}=0.0 \%\right)$.

Relative risk estimates of ever parous $(\geq 1$ child versus nulliparous) were reported in 16 lung cancer studies and 8 adenocarcinoma studies. We also found a significant negative association between parity and overall lung cancer risks among Asian women in both case-control and cohort studies $\left(\mathrm{OR}=0.56,95 \% \mathrm{CI}=0.47-0.67, I^{2}=\right.$ $11.4 \%)$. Forest plots of subgroup analyses are shown in Supplementary Figs. S2-S8, Additional file 2.

\section{Age at first birth}

Relative risk estimates for age at first birth were reported in 19 studies for overall lung cancer and 10 studies for adenocarcinoma (oldest age group versus youngest age group). The highest age at first birth category ranged from $\geq 25$ to $\geq 31$, and the lowest reference age at first birth category ranged from nulliparous to $<25$. The pooled ORs were $0.85\left(95 \% \mathrm{CI}=0.74-0.98, I^{2}=62.7 \%\right)$ and $0.84\left(95 \% \mathrm{CI}=0.74-0.95, I^{2}=36.9 \%\right)$ for overall lung cancer and adenocarcinoma risk for older age at 
Table 2 Association of significant reproductive factors and lung cancer risk, stratified by subgroups (highest vs. lowest category)

\begin{tabular}{|c|c|c|c|c|c|c|}
\hline \multirow[t]{2}{*}{ Reproductive factors $^{\mathrm{a}}$} & \multirow[t]{2}{*}{$\mathrm{n}$} & \multirow[t]{2}{*}{ OR $(95 \% \mathrm{CI})^{\mathrm{b}}$} & \multirow{2}{*}{$\begin{array}{l}\text { Case-Control } \\
\text { n }\end{array}$} & \multicolumn{3}{|l|}{ Cohort } \\
\hline & & & & OR $(95 \% \mathrm{Cl})^{\mathrm{b}}$ & $\mathrm{n}$ & OR $(95 \% \mathrm{Cl})^{\mathrm{b}}$ \\
\hline \multicolumn{7}{|l|}{ Parity (highest vs. lowest) } \\
\hline Overall lung cancer & 24 & $0.83(0.72,0.96)$ & 15 & $0.82(0.68,0.98)$ & 9 & $0.85(0.68,1.05)$ \\
\hline Asian & 12 & $0.70(0.58,0.86)$ & 7 & $0.81(0.65,1.01)$ & 5 & $0.58(0.44,0.75)$ \\
\hline Caucasian & 8 & $1.03(0.85,1.25)$ & 5 & $0.93(0.60,1.43)$ & 3 & $1.12(0.96,1.31)$ \\
\hline Adenocarcinoma & 10 & $0.83(0.63,1.09)$ & 5 & $1.00(0.82,1.22)$ & 5 & $0.71(0.43,1.16)$ \\
\hline Asian & 5 & $0.72(0.37,1.39)$ & 2 & $1.22(0.86,1.73)$ & 3 & $0.45(0.28,0.71)$ \\
\hline Caucasian & 4 & $0.93(0.76,1.13)$ & 2 & $0.74(0.44,1.24)$ & 2 & $0.97(0.78,1.20)$ \\
\hline Non-small cell lung cancer & 10 & $0.84(0.63,1.11)$ & 5 & $0.81(0.51,1.29)$ & 5 & $0.85(0.57,1.27)$ \\
\hline Asian & 4 & $0.82(0.33,2.07)$ & 2 & $1.22(0.86,1.73)$ & 2 & $0.39(0.18,0.84)$ \\
\hline Caucasian & 4 & $0.94(0.69,1.29)$ & 2 & $0.74(0.44,1.24)$ & 2 & $0.97(0.78,1.20)$ \\
\hline Never Smokers & 11 & $0.71(0.54,0.93)$ & 5 & $0.65(0.52,0.81)$ & 6 & $0.80(0.51,1.28)$ \\
\hline Asian & 7 & $0.65(0.54,0.78)$ & & & & \\
\hline Caucasian & 2 & $0.99(0.25,3.85)$ & & & & \\
\hline Ever Smokers & 8 & $0.78(0.59,1.04)$ & 4 & $0.56(0.41,0.75)$ & 4 & $1.01(0.76,1.34)$ \\
\hline Asian & 4 & $0.54(0.40,0.75)$ & & & & \\
\hline Caucasian & 2 & $1.14(0.92,1.40)$ & & & & \\
\hline \multicolumn{7}{|l|}{ Parity (highest vs. nulliparous) } \\
\hline Overall lung cancer & 16 & $0.77(0.62,0.95)$ & 10 & $0.79(0.62,1.00)$ & 6 & $0.72(0.49,1.06)$ \\
\hline Asian & 5 & $0.56(0.47,0.67)$ & 1 & $0.61(0.43,0.87)$ & 4 & $0.55(0.45,0.66)$ \\
\hline Caucasian & 8 & $0.96(0.73,1.26)$ & 6 & $0.83(0.58,1.18)$ & 2 & $1.22(0.97,1.52)$ \\
\hline Adenocarcinoma & 8 & $0.71(0.49,1.01)$ & 4 & $0.83(0.64,1.08)$ & 4 & $0.66(0.31,1.41)$ \\
\hline Asian & 3 & $0.45(0.28,0.71)$ & & & 3 & $0.45(0.28,0.71)$ \\
\hline Caucasian & 4 & $0.84(0.52,1.35)$ & 3 & $0.66(0.45,0.98)$ & 1 & $1.41(0.90,2.20)$ \\
\hline \multicolumn{7}{|l|}{ Age at first birth } \\
\hline Overall lung cancer & 19 & $0.85(0.74,0.98)$ & 12 & $0.77(0.61,0.97)$ & 7 & $0.94(0.81,1.08)$ \\
\hline Asian & 9 & $0.90(0.66,1.22)$ & & & & \\
\hline Caucasian & 6 & $0.75(0.65,0.88)$ & & & & \\
\hline Adenocarcinoma & 10 & $0.84(0.74,0.95)$ & 6 & $0.85(0.72,1.00)$ & 4 & $0.82(0.67,1.01)$ \\
\hline Asian & 3 & $0.62(0.47,0.83)$ & & & & \\
\hline Caucasian & 5 & $0.82(0.68,0.97)$ & & & & \\
\hline \multicolumn{7}{|l|}{ Non-natural menopause } \\
\hline Overall lung cancer & 11 & $1.52(1.25,1.86)$ & 6 & $1.83(1.50,2.22)$ & 5 & $1.17(1.00,1.37)$ \\
\hline Asian & 4 & $1.36(1.07,1.72)$ & & & & \\
\hline Caucasian & 5 & $1.67(1.12,2.49)$ & & & & \\
\hline Adenocarcinoma & 6 & $1.41(1.18,1.69)$ & 5 & $1.64(1.25,2.14)$ & 1 & $1.24(0.97,1.59)$ \\
\hline Caucasian & 5 & $1.44(1.19,1.74)$ & & & & \\
\hline \multicolumn{7}{|l|}{ Menstrual cycle length } \\
\hline Overall lung cancer & 7 & $0.79(0.65,0.96)$ & 7 & $0.79(0.65,0.96)$ & & \\
\hline Asian & 3 & $0.64(0.49,0.85)$ & & & & \\
\hline Caucasian & 4 & $0.98(0.74,1.28)$ & & & & \\
\hline Adenocarcinoma & 4 & $0.79(0.55,1.14)$ & 4 & $0.79(0.55,1.14)$ & & \\
\hline Caucasian & 3 & $0.79(0.51,1.21)$ & & & & \\
\hline
\end{tabular}


first birth, respectively (Tables 1 and 2). Among Asian women, older age at first birth was significantly negatively associated with adenocarcinoma risks $(\mathrm{OR}=0.62$, 95\% CI $=0.47-0.83, \quad I^{2}=0.0 \%$ ). Among Caucasian women with older age at first birth, overall lung cancer risk $\left(\mathrm{OR}=0.75,95 \% \mathrm{CI}=0.65-0.88, I^{2}=15.9 \%\right)$ was significantly lower than those with younger age at first birth, but this association was not significant among Asian women. We did a sensitivity analysis by excluding the nulliparous women to avoid conflating the effects of parity and age at first birth (only one study was excluded), and the result did not change (OR $=0.83,95 \%$ $\mathrm{CI}=0.72-0.96, I^{2}=61.7 \%$ ). Forest plots of subgroup analyses are shown in Supplementary Fig. S9, Additional file 2 .

\section{Non-natural menopause}

Relative risk estimates for non-natural menopause versus natural menopause were reported in 11 studies for overall lung cancer $\left(\mathrm{OR}=1.52,95 \% \mathrm{CI}=1.25-1.86, I^{2}=\right.$ $55.3 \%)$ and in 6 studies for adenocarcinoma (OR $=1.41$, 95\% CI $=1.18-1.69, I^{2}=0.0 \%$ ) (Tables 1 and 2). Nonnatural menopause was significantly associated with higher overall lung cancer risk, particularly among Caucasian women for overall lung cancer $(\mathrm{OR}=1.67,95 \%$ $\left.\mathrm{CI}=1.12-2.49, I^{2}=73.4 \%\right)$ and lung adenocarcinoma (OR $\left.=1.44,95 \% \mathrm{CI}=1.19-1.74, I^{2}=0.0 \%\right)$. A significant positive association with overall lung cancer risk was found among women with ovariectomy $(\mathrm{OR}=1.38,95 \%$ $\mathrm{CI}=1.16-1.64, I^{2}=0.0 \%$ ) (Supplementary Fig. S1, S10, Additional file 2).

\section{Menstrual cycle length}

The highest menstrual cycle length category was defined as more than 30 days, and the lowest reference menstrual cycle length category ranged from $<27$ to $\leq 30$ days. The association between menstrual cycle length (highest vs. lowest category) and lung cancer risk was reported in 7 studies for overall lung cancer $(\mathrm{OR}=0.79$,
95\% CI $\left.=0.65-0.96, I^{2}=42.7 \%\right)$ and in 4 studies for adenocarcinoma $\left(\mathrm{OR}=0.79,95 \% \mathrm{CI}=0.55-1.14, I^{2}=\right.$ $0.0 \%$ ) (Tables 1 and 2). Longer menstrual length was significantly associated with lower lung cancer risks among Asian women $\left(\mathrm{OR}=0.64,95 \% \mathrm{CI}=0.49-0.85, I^{2}=0.0 \%\right)$ (Supplementary Fig. S11, Additional file 2).

\section{Publication bias}

Publication bias was assessed using Egger's test, if there were at least 10 studies on the reproductive factor [94]. Results of Egger's test showed that studies among parity and menopause type may have publication bias (Table 3). This suggested the presence of a potential publication bias, a language bias, inflated estimates by a flawed methodologic design in smaller studies, and/or a lack of publication of small trials with opposite results. Therefore, we conducted the 'leave one out' sensitivity analysis to explore the heterogeneity among studies of parity and menopause type, and no individual study was found to have excessive influence on the pooled effect (Supplementary Fig. S12, Additional file 2).

\section{Sensitivity analysis}

In addition, we used the trim and fill method to test publication bias that conservatively imputes hypothetical negative unpublished studies to mirror the positive studies that cause funnel plot asymmetry. The imputed studies produce a symmetrical funnel plot (Supplementary Fig. S13, Additional file 2). The pooled analysis incorporating the hypothetical studies continued to show a statistically significant association between parity, menopause type, and lung cancer risk.

We assessed the quality of all the included studies by removing 7 studies with poor quality and a high level of bias (NOS score $\leq 5$ or CRBT score $<4$ ) for the sensitivity analysis (Supplementary Table 3-9, Additional file 1). The results did not change except for hormone use, and the effect of hormone use changed from borderline nonsignificant $\left(\mathrm{OR}=0.95,95 \% \mathrm{CI}=0.90-1.01, I^{2}=56.6 \%\right)$ to

Table 3 Egger's test for publication bias assessment (number of studies $\geq 10$ )

\begin{tabular}{lll}
\hline Variables & No. of studies & $\boldsymbol{P}$ value of Egger's test \\
\hline Hormone use & 38 & 0.498 \\
OC use & 26 & 0.565 \\
Parity & 24 & $\mathbf{0 . 0 4 1}$ \\
Age at menopause & 22 & 0.984 \\
Age at menarche & 20 & 0.841 \\
Age at first birth & 19 & 0.895 \\
Parity with nulliparous women as reference & 16 & 0.110 \\
OC use duration & 12 & 0.112 \\
Menopause type & 11 & $\mathbf{0 . 0 1 4}$ \\
Number of pregnancy & 10 & 0.559 \\
\hline
\end{tabular}


borderline significant $(\mathrm{OR}=0.93,95 \% \mathrm{CI}=0.88-0.99$, $\left.I^{2}=55.4 \%\right)$.

\section{Discussion}

Our meta-analysis of 20 reproductive factors revealed significant associations between parity, non-natural menopause, menstrual cycle length, and age at first pregnancy on lung cancer risk. Higher parity, older age at first pregnancy, and longer menstrual cycle length were associated with lower lung cancer risk. Conversely, nonnatural menopause such as ovariectomy was found to be associated with higher risk of lung cancer.

Previous meta-analysis studies reported no significant associations between parity and lung cancer risk, regardless of ethnicity or study design $[95,96]$. However, the number of included studies and different methods of calculating the risk ratios may account for the discrepancy. Two previous meta-analysis studies included a total of up to 21 studies before 2012 [95, 96]. They combined the estimates of the number of pregnancy and live birth, and Dahabreh et al.'s meta-analysis study [95] used both continuous and categorical risk estimates from published studies. In contrast, for parity, our meta-analysis only used categorical relative risk estimates extracted from 24 published studies and included 8 recent new studies after 2012 in addition to all the other studies that were included in the previous two meta-analyses. Relative risk estimates for the number of pregnancies and overall lung cancer risk reported by eight studies were included as an independent variable in our meta-analysis. Similar to Zhang et al. [96], we also found a significant negative association of lung cancer risk among women with longer menstrual cycle length. Shorter menstrual cycle length may increase the period of endogenous estrogen exposure (follicular phase), followed by increased cumulative exposure [97]. However, a previous meta-analysis found no significant association between older age at first birth and lung cancer risk [96].

There are several proposed mechanisms that have been hypothesized to explain the relationship between reproductive factors and the risk of lung cancer. Collectively, these factors are ascribed to the potential effects of estrogen on lung cancer risk. The hormonal etiology may play a direct role in the development of lung cancer. Estrogen and progesterone were associated with lung tumor proliferation, a process that can be triggered by hormonal receptors including estrogen receptors (ERs), progesterone, and epidermal growth factor (EGFR) receptors [98]. These receptors were found to be expressed in lung tumors $[99,100]$ and normal lung tissues [101], and they demonstrated regulatory effects in tumor growth and proliferation [10, 102-104]. Progesteronereceptors were reported to have tumor-suppressive effects, [105] while estrogen receptors were shown to stimulate tumor proliferation [106, 107]. Estrogen levels among women with lung cancer are usually higher than those in women without lung cancer [108]. Estrogenic stimulation in a murine xenograft model produced proliferative responses in lung tumor cell lines and increased tumor volumes [11]. Previous studies also reported that estrogen $\beta$ receptors promote estrogendependent growth of lung cancer cells $[109,110]$. In our study, we found negative associations between higher parity, older age at first pregnancy, and longer menstrual cycle length with lung cancer risk. Consistent with the proposed mechanisms, these protective reproductive factors are associated with lower estrogen levels in women $[97,111,112]$.

Furthermore, estrogen can directly stimulate the transcription of estrogen-responsive genes in the nucleus of lung cells, and transactivate growth factor signaling pathways, in particular the epidermal growth factor pathway $[100,113]$. EGFR mutations often occur among adenocarcinoma lung cancer subtypes, females, never-smokers, and East Asians [114-117]. In our study, we observed lower lung cancer risk among never-smokers and Asian women with higher parity, suggesting that higher parity is inversely associated with lung cancer risk by inhibiting EGFR activation or mutation. Estrogens may also influence lung carcinogenesis by their effect on carcinogen metabolism via the cytochrome P450 enzyme system [100].

We also found that non-natural menopause, including ovariectomy, was positively associated with lung cancer risk. However, the potential mechanisms remain unclear. This may be due to a sudden drop in circulating hormone levels after bilateral ovariectomy, unlike natural menopausal women whose circulating hormone levels decline gradually $[65,118,119]$. In addition, women with surgical menopause are usually placed on long-term hormone replacement therapy, which was previously shown to be associated with lung cancer risk [120]. However, there are controversies in the association between hormone replacement therapy and lung cancer risk [113].

Our meta-analysis has several limitations. First, we were unable to assess the dose-response effect or further stratify by other, or less common lung cancer histology types for most reproductive factors (e.g., squamous cell carcinoma, small cell lung cancer) because there were inadequate number of studies for such analyses. Second, the existing studies used different terms to describe hormone use (e.g., hormone replacement therapy, hormone therapy, postmenopausal hormone use, estrogen use, conjugated estrogen use, estrogen replacement use), thus we combined them and examined the overall association of hormone use on lung cancer risk. Hence, we may not be able to delineate the differential associations of the different hormone types. Third, given the different cutoffs used for reference category and confounder 
adjustments across different studies, our results might include trivial disparity and instability when evaluating the true impact of reproductive factors on lung cancer risk. Fourth, this analysis can only draw an inference on association of the reproductive factors with lung cancer risk, and not the cause-effect relationship. Finally, our inclusion of only published articles that were written either in English or in Chinese, and the exclusion of potentially relevant papers that were not publicly available may influence the publication bias of our study [121, 122].

Despite some of the existing limitations in our study, this is the first study to include a comprehensive review and meta-analysis of 20 reproductive factors, provide detailed stratification on each of the reproductive factor by lung cancer subtype, smoking status, ethnicity and study design, and assess the association between certain reproductive factors such as breastfeeding, ovariectomy, miscarriage, tubal sterilization use, reproductive period, length of menstrual flow, hysterectomy, intrauterine device use, and lung cancer risks among women.

\section{Conclusions}

In conclusion, we found a significant protective effect of higher parity, older age at first pregnancy, and longer menstrual cycle length on lung cancer risk, but a significant positive association between non-natural menopause with lung cancer risk. Increased parity had a negative association with lung cancer risk among neversmoking women. Future studies should validate the association between reproductive and menstrual exposures on lung cancer risks and investigate the underlying mechanisms.

\section{Supplementary information}

Supplementary information accompanies this paper at https://doi.org/10. 1186/s12889-020-09530-7.

\section{Additional file 1: Supplementary Table S1. Search strategy for relevant studies in PubMed. Supplementary Table S2. Characteristics of selected studies reporting the associations between reproductive factors and overall lung cancer risks. Supplementary Table S3-8. Quality assessment of the included studies. Supplementary Table S9. Sensitive analysis of the association of reproductive factors and overall lung cancer risk}

Additional file 2: Supplementary Figs. S1-13. Forest plots for lung cancer risks in women with reproductive variables

\section{Abbreviations}

OR: Odds ratio; Cl: Confidence interval; EGFR: Epidermal growth factor receptor; CNKI: Chinese National Knowledge Infrastructure;

AC: Adenocarcinoma; SCC: Squamous cell carcinoma; SCLC: Small-cell lung cancer; NSCLC: Non-small-cell lung cancer; RR: Risk ratio; SIR: Standardized incidence ratio; HR: Hazard ratio; EPT: Estrogen plus progestin; E: Estrogen alone; HRT: Hormone replacement therapy; ER: Estrogen receptor; NOS: Newcastle-Ottawa Scale; CRBT: Cochrane Risk of Bias Tool; PRIS MA: Preferred Reporting Items for Systematic Reviews and Meta-Analyses

\section{Acknowledgements}

Not applicable.

\section{Authors' contributions}

All authors have contributed significantly. XY and ZZ performed literature review, carried out the meta-analyses, wrote and revised the initial manuscript. DHH commented on the manuscript. QL and WJS conceptualized the study, critically reviewed the manuscript, and approved the final manuscript as submitted. All authors read and approved the final manuscript.

\section{Authors' information}

Not applicable.

\section{Funding}

This work was supported by the National University of Singapore Start-Up Grant

\section{Availability of data and materials}

Not applicable.

Ethics approval and consent to participate

Not applicable.

\section{Consent for publication}

Not applicable.

\section{Competing interests}

The authors declare that they have no competing interests.

\section{Author details}

${ }^{1}$ Saw Swee Hock School of Public Health, National University of Singapore and National University Health System, Singapore 117549, Singapore.

${ }^{2}$ Division of Cancer Epidemiology and Genetics, National Cancer Institute, National Institutes of Health, Rockville, MD 20850, USA. ${ }^{3}$ Dermatology Service, Department of Medicine, Memorial Sloan Kettering Cancer Center, New York, NY 10065, USA. ${ }^{4}$ Department of Epidemiology and Population Health, Albert Einstein College of Medicine, The Bronx, NY 10461, USA. ${ }^{5}$ Department of Medicine, Yong Loo Lin School of Medicine, National University of Singapore and National University Health System, Singapore 119228, Singapore.

Received: 24 February 2020 Accepted: 10 September 2020

Published online: 25 September 2020

References

1. Bray F, Ferlay J, Soerjomataram I, Siegel RL, Torre LA, Jemal A, Global cancer statistics 2018. GLOBOCAN estimates of incidence and mortality worldwide for 36 cancers in 185 countries. CA Cancer J Clin. 2018.

2. Chakraborty S, Ganti AK, Marr A, Batra SK. Lung cancer in women: role of estrogens. Expert Rev Respir Med. 2010;4(4):509-18.

3. Wakelee HA, Chang ET, Gomez SL, Keegan TH, Feskanich D, Clarke CA, et al. Lung cancer incidence in never smokers. J Clin Oncol. 2007;25(5):472-8.

4. Alberg AJ, Ford JG, Samet JM. American College of Chest P. epidemiology of lung cancer: ACCP evidence-based clinical practice guidelines (2nd edition). Chest. 2007;132(3 Suppl):29S-55S.

5. Thomas L, Doyle LA, Edelman MJ. Lung cancer in women: emerging differences in epidemiology, biology, and therapy. Chest. 2005;128(1):370-81.

6. Patel JD. Lung cancer in women. J Clin Oncol. 2005;23(14):3212-8.

7. Henschke Cl, Sone S, Hanaoka T, Markowitz S, Miller A, Klingler K, et al. Women's susceptibility to tobacco carcinogens and survival after diagnosis of lung cancer. JAMA J Am Med Assoc. 2006;296(2):180-4.

8. International Early Lung Cancer Action Program I, Henschke Cl, Yip R, Miettinen OS. Women's susceptibility to tobacco carcinogens and survival after diagnosis of lung cancer. JAMA. 2006;296(2):180-4.

9. Radzikowska E, Glaz P, Roszkowski K. Lung cancer in women: age, smoking, histology, performance status, stage, initial treatment and survival. Population-based study of 20561 cases. Ann Oncol. 2002;13(7):1087-93.

10. Mollerup S, Jorgensen K, Berge G, Haugen A. Expression of estrogen receptors alpha and beta in human lung tissue and cell lines. Lung Cancer. 2002;37(2):153-9.

11. Stabile LP, Davis AL, Gubish CT, Hopkins TM, Luketich JD, Christie N, et al. Human non-small cell lung tumors and cells derived from normal lung 
express both estrogen receptor alpha and beta and show biological responses to estrogen. Cancer Res. 2002;62(7):2141-50.

12. Rosell R, Moran T, Queralt C, Porta R, Cardenal F, Camps C, et al. Screening for epidermal growth factor receptor mutations in lung cancer. N Engl J Med. 2009;361(10):958-67.

13. Sellers TA, Potter JD, Folsom AR. Association of incident lung cancer with family history of female reproductive cancers: the lowa Women's health study. Genet Epidemiol. 1991;8(3):199-208.

14. Schwartz AG, Siegfried JM, Weiss L. Familial aggregation of breast cancer with early onset lung cancer. Genet Epidemiol. 1999;17(4):274-84.

15. Curtis RE, Hoover RN, Kleinerman RA, Harvey EB. Second cancer following cancer of the female genital system in Connecticut, 1935-82. Natl Cancer Inst Monogr. 1985;68:113-37.

16. Storm HH, Ewertz M. Second cancer following cancer of the female genital system in Denmark, 1943-80. Natl Cancer Inst Monogr. 1985;68:331-40.

17. Ewertz M, Mouridsen HT. Second cancer following cancer of the female breast in Denmark, 1943-80. Natl Cancer Inst Monogr. 1985;68:325-9.

18. Harvey EB, Brinton LA. Second cancer following cancer of the breast in Connecticut, 1935-82. Natl Cancer Inst Monogr. 1985;68:99-112.

19. Kabat GC. Aspects of the epidemiology of lung cancer in smokers and nonsmokers in the United States. Lung Cancer. 1996;15(1):1-20.

20. Kabat GC. Previous cancer and radiotherapy as risk factors for lung cancer in lifetime nonsmokers. Cancer Causes Control. 1993;4(5):489-95.

21. Frisch $M$, Melbye M. Risk of lung cancer in pre- and post-menopausal women with ano-genital malignancies. Int J Cancer. 1995;62(5):508-11.

22. Lim WY, Chen Y, Chuah KL, Eng P, Leong SS, Lim E, et al. Female reproductive factors, gene polymorphisms in the estrogen metabolism pathway, and risk of lung cancer in Chinese women. Am J Epidemiol. 2012; 175(6):492-503.

23. Paulus JK, Asomaning K, Kraft P, Johnson BE, Lin X, Christiani DC. Parity and risk of lung cancer in women. Am J Epidemiol. 2010;171(5):557-63.

24. Seow A, Koh WP, Wang R, Lee HP, Yu MC. Reproductive variables, soy intake, and lung cancer risk among nonsmoking women in the Singapore Chinese health study. Cancer Epidemiol Biomark Prev. 2009;18(3):821-7.

25. Schwartz AG, Wenzlaff AS, Prysak GM, Murphy V, Cote ML, Brooks SC, et al. Reproductive factors, hormone use, estrogen receptor expression and risk of non small-cell lung cancer in women. J Clin Oncol. 2007;25(36):5785-92.

26. Lo YL, Hsiao CF, Chang GC, Tsai YH, Huang MS, Su WC, et al. Risk factors for primary lung cancer among never smokers by gender in a matched casecontrol study. Cancer Causes Control. 2013;24(3):567-76.

27. Chen KY, Hsiao CF, Chang GC, Tsai YH, Su WC, Perng RP, et al. Hormone replacement therapy and lung cancer risk in Chinese. Cancer. 2007;110(8): 1768-75.

28. Elliott AM, Hannaford PC. Use of exogenous hormones by women and lung cancer: evidence from the Royal College of general Practitioners' Oral contraception study. Contraception. 2006;73(4):331-5.

29. Seng ZB, Jue WT, Di ZQ, Peng G, Wu JM. Risk factors analysis of lung adenocarcinoma in women. Chin J Public Health. 2000;16(6):536-9.

30. Taioli E, Wynder EL. Re: endocrine factors and adenocarcinoma of the lung in women. J Natl Cancer Inst. 1994;86(11):869-70.

31. Liu $Y$, Inoue $M$, Sobue $T$, Tsugane $S$. Reproductive factors, hormone use and the risk of lung cancer among middle-aged never-smoking Japanese women: a large-scale population-based cohort study. Int J Cancer. 2005; 117(4):662-6.

32. Higgins JP, Thompson SG, Deeks JJ, Altman DG. Measuring inconsistency in meta-analyses. BMJ. 2003;327(7414):557-60.

33. Egger M, Davey Smith $G$, Schneider M, Minder C. Bias in meta-analysis detected by a simple, graphical test. BMJ. 1997;315(7109):629-34.

34. Begg CB, Mazumdar M. Operating characteristics of a rank correlation test for publication bias. Biometrics. 1994;50(4):1088-101.

35. Moher D, Liberati A, Tetzlaff J, Altman DG, Group P. Preferred reporting items for systematic reviews and meta-analyses: the PRISMA statement. Int J Surg. 2010;8(5):336-41.

36. Gao YT, Blot WJ, Zheng W, Ershow AG, Cheng WH, Levin LI, et al. LungCancer among Chinese-women. Int J Cancer. 1987;40(5):604-9.

37. Wu AH, Yu MC, Thomas DC, Pike MC, Henderson BE. Personal and family history of lung-disease as risk-factors for adenocarcinoma of the lung. Cancer Res. 1988;48(24):7279-84.

38. Adami HO, Persson I, Hoover R, Schairer C, Bergkvist L. Risk of Cancer in women receiving hormone replacement therapy. Int J Cancer. 1989;44(5): 833-9.
39. Wuwilliams AH, Dai XD, Blot W, Xu ZY, Sun XW, Xiao HP, et al. Lung-Cancer among women in north-East China. Brit J Cancer. 1990;62(6):982-7.

40. Taioli E, Wynder EL. Endocrine factors and adenocarcinoma of the lung in women. J Natl Cancer I. 1994;86(11):869-70.

41. Persson I, Yuen J, Bergkvist L, Schairer C. Cancer incidence and mortality in women receiving estrogen and estrogen-progestin replacement therapy long-term follow-up of a Swedish cohort. Int J Cancer. 1996;67(3):327-32.

42. Zhou BS, Wang TJ, Guan P, Wu JM. Indoor air pollution and pulmonary adenocarcinoma among females: a case-control study in Shenyang, China. Oncol Rep. 2000;7(6):1253-9.

43. Pukkala E, Tulenheimo-Silfvast A, Leminen A. Incidence of cancer among women using long versus monthly cycle hormonal replacement therapy, Finland 1994-1997. Cancer Causes Control. 2001;12(2):111-5.

44. Blackman JA, Coogan PF, Rosenberg L, Strom BL, Zauber AG, Palmer JR, et al. Estrogen replacement therapy and risk of lung cancer. Pharmacoepidemiol Drug Saf. 2002;11(7):561-7.

45. Hulley S, Furberg C, Barrett-Connor E, Cauley J, Grady D, Haskell W, et al. Noncardiovascular disease outcomes during 6.8 years of hormone therapy heart and estrogen/progestin replacement study follow-up (HERS II). JAMA J Am Med Assoc. 2002;288(1):58-66.

46. Kubik AK, Zatloukal P, Tomasek L, Petruzelka L. Lung cancer risk among Czech women: a case-control study. Prev Med. 2002;34(4):436-44.

47. Rossouw JE, Anderson GL, Prentice RL, LaCroix AZ, Kooperberg C, Stefanick $M L$, et al. Risks and benefits of estrogen plus progestin in healthy postmenopausal women: principal results from the Women's Health Initiative randomized controlled trial. JAMA. 2002;288(3):321-33.

48. Seow A, Poh WT, Teh M, Eng P, Wang YT, Tan WC, et al. Diet, reproductive factors and lung cancer risk among Chinese women in Singapore: evidence for a protective effect of soy in nonsmokers. Int J Cancer. 2002:97(3):365-71.

49. Brenner AV, Wang ZY, Kleinerman RA, Lei SJ, Metayer C, Wang WL, et al. Menstrual and reproductive factors and risk of lung cancer among Chinese women, eastern Gansu Province, 1994-1998. J Epidemiol. 2003;13(1):22-8.

50. Kreuzer M, Gerken M, Heinrich J, Kreienbrock L, Wichmann HE. Hormonal factors and risk of lung cancer among women? Int J Epidemiol. 2003;32(2): 263-71.

51. Olsson H, Bladstrom A, Ingvar C. Are smoking-associated cancers prevented or postponed in women using hormone replacement therapy? Obstet Gynecol. 2003;102(3):565-70.

52. Schabath MB, Wu XF, Vassilopoulou-Sellin R, Vaporciyan AA, Spitz MR. Hormone replacement therapy and lung cancer risk. A case-control analysis. Cancer Epidem Biomar. 2003;12(11):1294s-s.

53. Zatloukal P, Kubik A, Pauk N, Tomasek L, Petruzelka L. Adenocarcinoma of the lung among women: risk associated with smoking, prior lung disease, diet and menstrual and pregnancy history. Lung Cancer. 2003;41(3):283-93.

54. Gorlova OY, Zhang Y, Schabath MB, Lei L, Zhang Q, Amos Cl, et al. Never smokers and lung cancer risk: a case-control study of epidemiological factors. Int J Cancer. 2006;118(7):1798-804.

55. Kabat GC, Miller AB, Rohan TE. Reproductive and hormonal factors and risk of lung cancer in women: a prospective cohort study. Int J Cancer. 2007; 120(10):2214-20.

56. Matsuo $\mathrm{K}$, Ito $\mathrm{H}$, Yatabe $\mathrm{Y}$, Hiraki A, Hirose $\mathrm{K}$, Wakai $\mathrm{K}$, et al. Risk factors differ for non-small-cell lung cancers with and without EGFR mutation: assessment of smoking and sex by a case-control study in Japanese. Cancer Sci. 2007;98(1):96-101.

57. Ramnath N, Menezes RJ, Loewen G, Dua P, Eid F, Alkhaddo J, et al. Hormone replacement therapy as a risk factor for non-small cell lung cancer: results of a case-control study. Oncology. 2007;73(5-6):305-10.

58. Corrao G, Zambon A, Conti V, Nicotra F, La Vecchia C, Fornari C, et al. Menopause hormone replacement therapy and cancer risk: an Italian record linkage investigation. Ann Oncol. 2008;19(1):150-5.

59. Mahabir S, Spitz MR, Barrera SL, Dong YQ, Eastham C, Forman MR. Dietary boron and hormone replacement therapy as risk factors for lung cancer in women. Am J Epidemiol. 2008;167(9):1070-80.

60. Rodriguez C, Spencer Feigelson H, Deka A, Patel AV, Jacobs EJ, Thun MJ, et al. Postmenopausal hormone therapy and lung cancer risk in the cancer prevention study II nutrition cohort. Cancer Epidemiol Biomark Prev. 2008; 17(3):655-60.

61. Weiss JM, Lacey JV Jr, Shu XO, Ji BT, Hou L, Yang G, et al. Menstrual and reproductive factors in association with lung cancer in female lifetime nonsmokers. Am J Epidemiol. 2008;168(11):1319-25. 
62. Chlebowski RT, Schwartz AG, Wakelee H, Anderson GL, Stefanick ML, Manson JE, et al. Oestrogen plus progestin and lung cancer in postmenopausal women (Women's Health Initiative trial): a post-hoc analysis of a randomised controlled trial. Lancet.

2009;374(9697):1243-51.

63. Dorjgochoo T, Shu XO, Li HL, Qian HZ, Yang G, Cai H, et al. Use of oral contraceptives, intrauterine devices and tubal sterilization and cancer risk in a large prospective study, from 1996 to 2006. Int J Cancer. 2009;124(10): 2442-9.

64. Heck JE, Andrew AS, Onega T, Rigas JR, Jackson BP, Karagas MR, et al. Lung Cancer in a US population with low to moderate arsenic exposure. Environ Health Perspect. 2009;117(11):1718-23.

65. Koushik A, Parent ME, Siemiatycki J. Characteristics of menstruation and pregnancy and the risk of lung cancer in women. Int J Cancer. 2009;125(10): 2428-33.

66. Rosenblatt KA, Gao DL, Ray RM, Nelson ZC, Wernli KJ, Li W, et al. Oral contraceptives and the risk of all cancers combined and site-specific cancers in Shanghai. Cancer Causes Control. 2009;20(1):27-34.

67. Smith JR, Barrett-Connor E, Kritz-Silverstein D, Wingard DL, Al-Delaimy WK. Hormone use and lung cancer incidence: the rancho Bernardo cohort study. Menopause. 2009;16(5):1044-8.

68. Baik CS, Strauss GM, Speizer FE, Feskanich D. Reproductive factors, hormone use, and risk for lung cancer in postmenopausal women, the Nurses' health study. Cancer Epidemiol Biomark Prev. 2010;19(10):2525-33.

69. Brenner DR, Hung RJ, Tsao MS, Shepherd FA, Johnston MR, Narod S, et al. Lung cancer risk in never-smokers: a population-based case-control study of epidemiologic risk factors. BMC Cancer. 2010;10.

70. Chlebowski RT, Anderson GL, Manson JE, Schwartz AG, Wakelee H, Gass M, et al. Lung cancer among postmenopausal women treated with estrogen alone in the women's health initiative randomized trial. J Natl Cancer Inst. 2010;102(18):1413-21.

71. Slatore CG, Chien JW, Au DH, Satia JA, White E. Lung cancer and hormone replacement therapy: association in the vitamins and lifestyle study. J Clin Oncol. 2010;28(9):1540-6.

72. Brinton LA, Gierach GL, Andaya A, Park Y, Schatzkin A, Hollenbeck AR, et al Reproductive and hormonal factors and lung cancer risk in the NIH-AARP diet and health study cohort. Cancer Epidemiol Biomark Prev. 2011;20(5): 900-11.

73. Clague J, Reynolds P, Sullivan-Halley J, Ma H, Lacey JV Jr, Henderson KD, et al. Menopausal hormone therapy does not influence lung cancer risk: results from the California teachers study. Cancer Epidemiol Biomark Prev. 2011;20(3):560-4.

74. Meinhold CL, Berrington de Gonzalez A, Bowman ED, Brenner AV, Jones RT, Lacey JV Jr, et al. Reproductive and hormonal factors and the risk of nonsmall cell lung cancer. Int J Cancer. 2011;128(6):1404-13.

75. Brinton LA, Schwartz L, Spitz MR, Park Y, Hollenbeck AR, Gierach GL. Unopposed estrogen and estrogen plus progestin menopausal hormone therapy and lung cancer risk in the NIH-AARP diet and health study cohort. Cancer Causes Control. 2012;23(3):487-96.

76. Lin Y, Cai L. Environmental and dietary factors and lung cancer risk among Chinese women: a case-control study in Southeast China. Nutr Cancer. 2012;64(4):508-14.

77. Gallagher LG, Rosenblatt KA, Ray RM, Li W, Gao DL, Applebaum KM, et al. Reproductive factors and risk of lung cancer in female textile workers in Shanghai, China. Cancer Causes Control. 2013;24(7):1305-14.

78. Pesatori AC, Carugno M, Consonni D, Caporaso NE, Wacholder S, Tucker M, et al. Reproductive and hormonal factors and the risk of lung cancer: the EAGLE study. Int J Cancer. 2013;132(11):2630-9.

79. Schwartz AG, Ray RM, Cote ML, Abrams J, Sokol RJ, Hendrix SL, et al. Hormone use, reproductive history, and risk of lung Cancer: the Women's Health Initiative studies. J Thorac Oncol. 2015;10(7):1004-13.

80. Tan HS, Tan MH, Chow KY, Chay WY, Lim WY. Reproductive factors and lung cancer risk among women in the Singapore breast Cancer screening project. Lung Cancer. 2015;90(3):499-508.

81. Patel MI, Wang A, Kapphahn K, Desai M, Chlebowski RT, Simon MS, et al. Racial and ethnic variations in lung Cancer incidence and mortality: results from the Women's Health Initiative. J Clin Oncol. 2016;34(4):360-8.

82. Ben Khedher S, Neri M, Papadopoulos A, Christiani DC, Diao N, Harris CC, et al. Menstrual and reproductive factors and lung cancer risk: a pooled analysis from the international lung cancer consortium. Int J Cancer. 2017; 141(2):309-23.
83. He F, Xie JX, Liu CL, Xiong WM, Xu QP, Liu ZQ, et al. The relationship of lung cancer with menstrual and reproductive factors may be influenced by passive smoking, cooking oil fumes, and tea intake: a case-control study in Chinese women. Medicine (Baltimore). 2017;96(46):e8816.

84. Iversen L, Sivasubramaniam S, Lee AJ, Fielding S, Hannaford PC. Lifetime cancer risk and combined oral contraceptives: the Royal College of General Practitioners' Oral Contraception Study. Am J Obstet Gynecol. 2017, 216;(6): 580 e1-9.

85. W Z, YT G, L S. A study on the association between lung cancer and menstrual and reproductive history. (in Chinese). Tumor. 1988;8(3):150-3.

86. Xea L. Risk status analysis of female lung cancer. (in Chinese). J Jinan University. 1995;16(2):18-22.

87. Xiang Yea. 2003 A population-based case-control study of lung cancer between young and older nonsmoking women in urban Shanghai, P. R. China. (in Chinese). Tumor. 2003;23(6):452-7.

88. Zea Y. A case-control study on relationship between lung cancer in nonsmoking women and menstrual and reproductive factors. (in Chinese). Chin J. Public Health. 2005;21(12):1456-7.

89. Wea C. A cohort study on risk factors of lung cancer among nonsmoking women in urban Shanghai. (in Chinese): Fudan University; 2009.

90. $\mathrm{Y} L, X \mathrm{C}, \mathrm{M} \mathrm{H}$. A case-control study of risk factors for female lung cancer. (in Chinese). J Fujian Med Univ. 2010;44(4):239-43.

91. Jin K, Wu M, Zhou JY, Yang J, Han RQ, Jin ZY, et al. Tobacco smoking modifies the association between hormonal factors and lung Cancer occurrence among post-menopausal Chinese women. Transl Oncol. 2019; 12(6):819-27.

92. Titan AL, He H, Lui N, Liou D, Berry M, Shrager J, et al. The Influence of Hormone Replacement Therapy on Lung Cancer Incidence and Mortality. J Thorac Cardiovasc Surg. 2019.

93. Vohra SN, Sapkota A, Lee MT, Pun CB, Thakur B, Siwakoti B, et al. Reproductive and hormonal factors in relation to lung Cancer among Nepali women. Front Oncol. 2019;9:311.

94. Sterne JAC, Gavaghan D, Egger M. Publication and related bias in metaanalysis: power of statistical tests and prevalence in the literature. J Clin Epidemiol. 2000;53:1119-29.

95. Dahabreh IJ, Trikalinos TA, Paulus JK. Parity and risk of lung cancer in women: systematic review and meta-analysis of epidemiological studies. Lung Cancer. 2012;76(2):150-8.

96. Zhang Y, Yin Z, Shen L, Wan Y, Zhou B. Menstrual factors, reproductive factors and lung cancer risk: a meta-analysis. Chin J Lung Cancer. 2012; 15(12):701-19.

97. Lenton EA, Landgren BM, Sexton L, Harper R. Normal variation in the length of the follicular phase of the menstrual cycle: effect of chronological age. $\mathrm{Br}$ J Obstet Gynaecol. 1984;91(7):681-4.

98. Siegfried JM, Hershberger PA, Stabile LP. Estrogen receptor signaling in lung cancer. Semin Oncol. 2009;36(6):524-31.

99. Kaiser U, Hofmann J, Schilli M, Wegmann B, Klotz U, Wedel S, et al. Steroidhormone receptors in cell lines and tumor biopsies of human lung cancer. Int J Cancer. 1996;67(3):357-64.

100. Stabile LP, Siegfried JM. Estrogen receptor pathways in lung cancer. Curr Oncol Rep. 2004;6(4):259-67.

101. Fasco MJ, Hurteau GJ, Spivack SD. Gender-dependent expression of alpha and beta estrogen receptors in human nontumor and tumor lung tissue. Mol Cell Endocrinol. 2002;188(1-2):125-40.

102. Kawai H, Ishii A, Washiya K, Konno T, Kon H, Yamaya C, et al. Estrogen receptor alpha and beta are prognostic factors in non-small cell lung cancer. Clin Cancer Res. 2005;11(14):5084-9.

103. Nemenoff RA, Winn RA. Role of nuclear receptors in lung tumourigenesis. Eur J Cancer. 2005;41(16):2561-8.

104. Omoto Y, Kobayashi Y, Nishida K, Tsuchiya E, Eguchi H, Nakagawa K, et al. Expression, function, and clinical implications of the estrogen receptor beta in human lung cancers. Biochem Biophys Res Commun. 2001;285(2):340-7.

105. Ishibashi H, Suzuki T, Suzuki S, Niikawa H, Lu L, Miki Y, et al. Progesterone receptor in non-small cell lung cancer--a potent prognostic factor and possible target for endocrine therapy. Cancer Res. 2005;65(14):6450-8.

106. Hershberger PA, Vasquez AC, Kanterewicz B, Land S, Siegfried JM, Nichols M. Regulation of endogenous gene expression in human nonsmall cell lung cancer cells by estrogen receptor ligands. Cancer Res. 2005;65(4):1598-605. 
107. Marquez-Garban DC, Chen HW, Fishbein MC, Goodglick L, Pietras RJ. Estrogen receptor signaling pathways in human non-small cell lung cancer. Steroids. 2007;72(2):135-43.

108. Tiutiunova AM, Chirvina ED, Mironenko TV, Kartashov SZ, Luntovskaia VA. Hormonal balance in women with lung cancer and its changes after combined treatment. Vopr Onkol. 1986;32(4):26-30.

109. Lin S, Lin CJ, Hsieh DP, Li LA. ERalpha phenotype, estrogen level, and benzo [a] pyrene exposure modulate tumor growth and metabolism of lung adenocarcinoma cells. Lung Cancer. 2012;75(3):285-92.

110. Tsuchiya Y, Nakajima M, Yokoi T. Cytochrome P450-mediated metabolism of estrogens and its regulation in human. Cancer Lett. 2005;227(2):115-24.

111. Barrett ES, Parlett LE, Windham GC, Swan SH. Differences in ovarian hormones in relation to parity and time since last birth. Fertil Steril. 2014; 101(6):1773-80 e1.

112. Mumford SL, Steiner AZ, Pollack AZ, Perkins NJ, Filiberto AC, Albert PS, et al. The utility of menstrual cycle length as an indicator of cumulative hormonal exposure. J Clin Endocrinol Metab. 2012;97(10):E1871-9.

113. Hsu LH, Chu NM, Kao SH. Estrogen, Estrogen Receptor and Lung Cancer. Int J Mol Sci. 2017;18(8).

114. Sharma SV, Bell DW, Settleman J, Haber DA. Epidermal growth factor receptor mutations in lung cancer. Nat Rev Cancer. 2007;7(3):169-81.

115. Shigematsu H, Gazdar AF. Somatic mutations of epidermal growth factor receptor signaling pathway in lung cancers. Int J Cancer. 2006;1 18(2):257-62.

116. Shigematsu H, Lin L, Takahashi T, Nomura M, Suzuki M, Wistuba II, et al. Clinical and biological features associated with epidermal growth factor receptor gene mutations in lung cancers. J Natl Cancer Inst. 2005:97(5):339-46.

117. Sun S, Schiller JH, Gazdar AF. Lung cancer in never smokers--a different disease. Nat Rev Cancer. 2007;7(10):778-90.

118. Gelfand MM. Role of androgens in surgical menopause. Am J Obstet Gynecol. 1999;180(3 Pt 2):S325-7.

119. Hendrix SL. Bilateral oophorectomy and premature menopause. Am J Med. 2005;118(Suppl 12B):131-5.

120. Parker WH. Ovarian conservation versus bilateral oophorectomy at the time of hysterectomy for benign disease. Menopause. 2014;21 (2):192-4.

121. Gregoire G, Derderian F, Le Lorier J. Selecting the language of the publications included in a meta-analysis: is there a tower of babel bias? J Clin Epidemiol. 1995:48(1):159-63.

122. LeLorier J, Gregoire G, Benhaddad A, Lapierre J, Derderian F. Discrepancies between meta-analyses and subsequent large randomized, controlled trials. New Engl J Med. 1997;337(8):536-42.

\section{Publisher's Note}

Springer Nature remains neutral with regard to jurisdictional claims in published maps and institutional affiliations.

Ready to submit your research? Choose BMC and benefit from:

- fast, convenient online submission

- thorough peer review by experienced researchers in your field

- rapid publication on acceptance

- support for research data, including large and complex data types

- gold Open Access which fosters wider collaboration and increased citations

- maximum visibility for your research: over $100 \mathrm{M}$ website views per year

At $\mathrm{BMC}$, research is always in progress.

Learn more biomedcentral.com/submissions 